\title{
On the Costs and Benefits of Aggressive Judicial Review of Agency Action
}

\section{Citation}

Cass R. Sunstein, On the Costs and Benefits of Aggressive Judicial Review of Agency Action, 1989 Duke L. J. 522 (1989).

\section{Published Version}

http://scholarship.law.duke.edu/dlj/vol38/iss3/2/

\section{Permanent link}

http://nrs.harvard.edu/urn-3:HUL.InstRepos:12809461

\section{Terms of Use}

This article was downloaded from Harvard University's DASH repository, and is made available under the terms and conditions applicable to Other Posted Material, as set forth at http:// nrs.harvard.edu/urn-3:HUL.InstRepos:dash.current.terms-of-use\#LAA

\section{Share Your Story}

The Harvard community has made this article openly available.

Please share how this access benefits you. Submit a story.

\section{Accessibility}




\title{
ON THE COSTS AND BENEFITS OF AGGRESSIVE JUDICIAL REVIEW OF AGENCY ACTION
}

\author{
CAss R. Sunstein*
}

In this essay, I undertake three tasks. The first is to describe some of the difficulties of defining "benefits" in the setting of judicial review of administrative action. The second task is to offer reasons, though tentative and largely anecdotal ones, for an affirmative answer to the question whether aggressive judicial review has produced "net benefits." At the very least, I suggest, aggressive judicial review has had significant benefits in many settings. The third and final task is to outline some proposals by which to increase the benefits, and decrease the risks, of an aggressive judicial posture in administrative law.

\section{The VARIous "Benefits" of Judicial Review}

For those assessing the value of judicial review of administrative action, the first problem is one of definition. In this context, the criteria for evaluation are elusive, and shift dramatically with context. Even so, it is possible to identify at least four different sets of criteria, all of which have been invoked in recent discussion. ${ }^{1}$

\section{A. Legality.}

The inost obvious goal, or "benefit," of judicial review is to increase the incidence of legality. Under this view, ${ }^{2}$ judicial review of administrative action is necessary above all to ensure that regulatory agencies comply with congressional coinmands. Far from being an enemy of the deinocractic process, judicial review is its indispensable ally, since it ensures adininistrative fidelity to public desires expressed in legislative com1nands. A major premise of this view is that implementing agencies have an electoral pedigree inferior to that of the Congress-the constitution-

* Karl N. Llewellyn Professor of Jurisprudence, Law School and Department of Political Science, University of Chicago. This essay is a revised version of a talk delivered to the section on administrative law of the Association of American Law Schools in January 1989.

1. See generally Cramton, A Comment on Trial-Type Hearings in Nuclear Power Plant Siting, 58 VA. L. REV. 585, 591-93 (1972).

2. See, e.g., P. Strauss, AN InTroduction to ADMINISTRATIVe JUSTICE IN THE UNITED STATES 261 (1989); see also F.A. VON HAYEK, THE CONSTITUTION OF LIBERTY 153-54 (1960). 
ally specified institution in the design of federal law. ${ }^{3}$

If legality is the goal of judicial review, active judicial review might well be desirable. There are good reasons to beheve that courts have a comparative advantage over agencies in deciding what the law is. ${ }^{4}$ But an increase in legality might not improve social welfare by any measure. A statute might be foolish, for example; it might impose costs that outweigh any benefits. A possible example is the Delaney. Clause, ${ }^{5}$ which forbids any carcinogens in food additives. The prohibition apphes to carcinogens posing trivial risks, and for that reason it has the potential to impose costs-including harms to health resulting from the substitution of noncarcinogenic but risky substances for carcinogenic substances posing de minimis risks-that would dwarf its benefits. ${ }^{6}$. A court that required literal coinpliance with the Delaney Clause inight increase legality but decrease net social benefits.

\section{B. Efficient Resource Allocation.}

Under a second view, the goal of judicial review is to proinote efficient resource allocation. ${ }^{7}$ The principal concern here is that regulatory

3. For criticism of this view, see Mashaw, Prodelegation: Why Administrators Should Make Political Decisions, 1 J.L. ECON. \& ORG. 81, 91-99 (1985) (arguing for broad statutory delegation of authority to administrators).

4. For a defense of this proposition, see Sunstein, Constitutionalism After the New Deal, 101 HARV. L. REV. 42 I, 464-69 (1987); for critical discussion, see Diver, Statutory Interpretation in the Administrative State, 133 U. PA. L. REV. 549, 582-92 (1985) (favoring interpretive competence of agencies).

If the goal of judicial review is to promote legality, an expansive interpretation of Chevron, U.S.A., Inc. v. NRDC, 467 U.S. 837, 843 (1984) (suggesting that courts should defer to agency interpretations of law when the statute is ambiguous or when Congress has not "directly addressed the precise question at issue"), would be a serious mistake. Courts could not defer to congressional interpretations of ambiguous constitutional provisions without grossly distorting basic principles of separation of powers. So too, judicial deference to agency views about "pure" questions of statutory meaning would upset longstanding principles to the effect that those limited by legal authority should not be empowered to decide on the scope of the limitation. Foxes, in short, should not guard henhouses. See Sunstein, supra, at 464-69.

One might emphasize this point while at the same time agreeing that courts should defer to agency views when Congress has told them to do so, or to agency views on questions, including legal questions, that call for the distinctive factfinding and policymaking competence of the agency-a point that supports the result in Chevron itself. A respect for the judicial role in deciding on the scope of an agency's legal authority, for the agency's institutional competence, and for Congress' power to allocate interpretive authority, all appear to underlie the discussion in INS v. CardozaFonseca, 480 U.S. 421 (1987)-perhaps the most sensible treatment of these issues in the last two decades.

5. Food Additives Amendment of 1958, Pub. L. No. 85-929, 72 Stat. 1784 (1958) (codified at 21 U.S.C. $\S \S 321,331,342,346,348,451$ (1982)).

6. See Merrill, FDA's Implementation of the Delaney Clause: Repudiation of Congressional Choice or Reasoned Adaptation to Scientific Progress?, 5 YALE J. ON REG. 1 (1988).

7. See Cramton, supra note 1 , at 592-93. 
agencies might undertake action whose real-world benefits are exceeded or even dwarfed by their real-world costs, measured in economic terms. In these circumstances, judicial review might serve as a corrective. Courts might, for example, ensure agamst excessive intervention in the marketplace; or they might compel agencies to consider the effects of private conduct-for example, pollution-whose extremely high social costs are insufficiently taken into account by the marketplace.

If the goal of judicial review is efficient resource allocation, that goal might be promoted as a result of judicial invalidation of agency action or maction deemed "arbitrary" or "capricious." efficient resource allocation may or may not overlap with other beneficial goals, such as compliance with a statute ("legality"). Statutory requirements sometimes promote the goal of efficient resource allocation, but frequently they are directed toward other ends, and in such cases the promotion of legality will conflict with the goal of efficient resource allocation.

\section{Real-World Improvements of an Eclectic Sort.}

A third conception of the purpose of judicial review also focuses on real-world improvements, but selects a quite different set of goals. Under this view, ${ }^{9}$ courts should not only promote better resource allocation in an economic sense, but might also, or even alternatively, attempt to: (a) ensure a better distribution of wealth; (b) promote the various nonmarket or noncommodity values contained in statutes that, for example, regulate broadcasting or protect endangered species and the environment; ${ }^{10}$ and (c) work against discrimination directed at various groups, including blacks, women, and the handicapped.

On this view, one would evaluate judicial review by asking if it brings about these various goals. Net benefits would be found when courts sensibly promote these goals; net costs would be found if they fail to do so. Here, too, the connection between legality in the sense of adherence to statute and real-world improvements is uncertain and sometimes merely coincidental. But since many statutes are in fact designed to promote goals of this sort, judicial efforts to ensure fidelity to law will often also result in practical changes in this direction.

8. 5 U.S.C. $\S 706(2)(\mathrm{A})$ (1982) (directing judges to invalidate agency action found arbitrary or capricious). goals).

9. Cf. C. Sunstein, The Regulatory State chs. 1-2 (1989 draft) (discussing diverse statutory

10. See Stewart, Regulation in a Liberal State: The Role of Non-Commodity Values, 92 YALE L.J. 1537 (1983). 


\section{Legitimacy.}

Under the traditional view, associated most closely with the work of Kenneth Culp Davis and Louis Jaffe, the basic function of the courts might be described as the promotion of "legitimacy" in the administrative process. ${ }^{11}$ This is an ill-defined concept, but it is associated with such conventional notions as ensurance of legality, protection against arbitrariness and selectivity, promotion of procedural regularity, and ensurance against the twin evils of factional tyranny and self-interested representation. A particular fear of this view is that well-organized private groups ("special interests") often have disproportionate influence over administrative processes-a phenomenon that provides the basic insight behind the extensive literature on agency "capture."12

This view places great emphasis on judicial independence, which serves as an iniportant safeguard, providing both an ex ante deterrent and as an ex post check against the donination of administrative processes by irrelevant or illegitimate considerations. On this view, moreover, an aggressive judicial role is necessary in order to introduce some of the traditional virtues of Anglo-American law into the administrative process. Here, as with the goal of legality, the "benefits" of judicial review are not evaluated directly in terms of its consequences for the world. The goals of judicial review are of a more diffuse sort, and have no necessary or linear connection with good regulatory outconies.

Both critical and approving evaluations of the judicial process are often confused by a failure to distinguish among these various criteria. Thus, for example, courts have been criticized for adhering to statutory text at society's expense, and at the same time for promoting social welfare at the expense of the statutory text. ${ }^{13}$ Courts might do an excellent job of pronioting fidelity to law, but at the same time, and perhaps as a direct result, bring about a less sensible system of regulation. By the same token, courts might introduce necessary regulatory controls but do so with a weak or uncertain statutory warrant.

In assessing judicial review, then, it is important to be careful to spcll out the relevant criteria. While selection of those criteria is a value-

11. See K. Davis, Administrative Law Treatise § 29.1 (2d ed. 1979); L. JAfFe, Judicial CONTROL OF ADMINISTRATIVE ACTION (1965).

12. See generally THE Politics of Regulation (J. Wilson ed. 1981) (collection of essays seeking to determine how regulatory agencies ordinarily operate and develop to their degree of influence by private powers); P. QUIRK, INDUSTRY INFLUENCE IN FEDERAL REGULATORY AGENCIES (1981) (addressing incentives acting on regulatory agencies to adopt pro-industry policies); $\mathrm{K}$. SCHLOZMAN \& J. T1ERNEY, ORGANIZED INTERESTS AND AMERICAN DEMOCRACY (1986).

13. An example is R. Melnick, Regulation and the Courts: THE CASE of the Clean AIR ACT (1983) (examining how federal courts have influenced policymaking in the regulation of air pollution), which, despite its numerous virtues, suffers from this problem. 
laden task, it is probably fair to say that both courts and observers have paid less attention than they should to the effects of judicial review on the real world of regulation-effects that are crucial to an evaluation of the judicial role. It is in large part because of our considerable ignorance on this score that the study of admimistrative law remains in a primitive state.

\section{The "Net Benefits" Produced by Aggressive JUDICIAL REVIEW}

Whatever the relevant criteria, it is difficult to make confident statements in the abstract, about the benefits and costs of aggressive judicial review of administrative action. It is surely imaginable, in certain times and places, that aggressive judicial review will both increase illegality and decrease social welfare on any view. Indeed, one could argue that this was precisely the pattern in the period immediately before and after the New Deal, when courts invoked a principle calling for narrow construction of regulatory power. ${ }^{14}$

More recently, aggresśive judicial review has produced regulatory irrationality in a variety of areas. Professor Mashaw has shown that the courts' simultaneous hospitality toward administrative recalls of defective vehicles and hostility toward ex ante motor vehicle regulation have pushed automobile safety regulation in peculiar directions. The net result tends toward regulation through random, ex post directives rather than through managerially coherent, ex ante controls. ${ }^{15}$ In the same vem, the courts' hiteral approach to the Delaney Clause has increased regulatory irrationality by imposing serious costs and in fact bringing about fewer rather than more improvements in safety and health. ${ }^{16}$

On the other hand, it is fully imaginable that aggressive judicial review will both increase legality and improve social welfare. Commentators can invoke considerations at a high level of generality that bear on this problem, and indeed such considerations form the staple of academic

14. See, e.g., FTC v. Eastman Kodak Co., 274 U.S. 619, 625 (1927) (Cornmission had no authority to require company to divest labs acquired before action by Commission); FTC v. Gratz, 253 U.S. 421, 427 (1920) (meaning of "unfair method of competition" is for the courts, not the Commission, to determine). See generally Fordham \& Leach, Interpretation of Statutes in Derogation of the Common Law, 3 VAND. L. REV. 438 (1950) (noting increasing reliance on statutes rather than common law), and cases cited therein.

15. See Mashaw \& Harsft, Regulation and Legal Culture: The Case of Motor Vehicle Safety, 4 YALE J. ON REG. 257, 263 (1987) (arguing that judicial review is a cause of National Highway Traffic Safety Administration's shift from rules to recalls).

16. See, eg., 'Public Citizen v. Young, 831 F.2d 1108, 1111-22 (D.C. Cir. 1987), cert. denied, 108 S. Ct. 1470 (1988) (Delaney Clause does not contain an implicit de minimus exception; FDA listing decisions for Orange No. 17, with cancer risk of 1 in 19 billion, and Red No. 19, with cancer risk of 1 in 9 million, must be changed). 
debates on these matters. Judicial lack of accountability, the judges' ignorance of the often complex matters at hand, the delays and formality built into the litigation process, and the courts ad hoc, case-by-case approach to regulatory issues are certainly likely to impair judicial performance in overseeing administration. ${ }^{17}$ At the same time, judicial independence might serve as a protection against the various pressures that produce administrative illegality, injustice, and irrationality. ${ }^{18}$ In recent years, there has been extensive documentation of the distorting effects of various pressures placed on regulators. ${ }^{19}$ Such evidence provides at least a plausible basis to believe that courts, precisely because of their independence, will provide a crucial deterrent and ex post corrective.20

Pitched at this level of generality, however, considerations of this sort are unlikely to be conclusive. Much will depend on context-on the particular substantive area and on the incentives, good faith, and competence of judges and administrators at any particular time. An evaluation of how these considerations have in fact played out over the past, say, fifty years must await extensive empirical investigation.

Even in the absence of a systematic treatment, however, it is possible to point to reasons to beheve that aggressive judicial review, evaluated under any criterion, has been desirable in many contexts. Aggressive review serves as a powerful ex ante deterrent to lawless or irrational agency behavior. In some settings, it also strengthens both analytic processes and accountability to superiors within agencies. ${ }^{21}$ In this sense, judicial review should be evaluated in terms of its systemic consequences for the administrative process, which takes place in the shadow of judicial review. Those consequences frequently have been desirable, above all because of the in terroram effect of the prospect of judicial scrutiny. A brief look at recent Office of Management and Budget (OMB) reports on

17. See Diver, supra note 4 , at 592-93 (finding that on whole agencies are better statutory interpreters than courts); Stewart, The Discontents of Legalism: Interest Group Relations in Administrative Regulation, 1985 WISC. L. REV. 655, 678-82 (litigation in administrative context causes delay and uncertainty).

18. See Pedersen, Formal Records and Informal Rulemaking, 85 YALE L.J. 38, 59-60 (1975) (judicial review of regulatory decisions would establish precedents for future rule-writers); Stewart, The Development of Administrative and Quasi-Constitutional Law in Judicial Review of Environmental Decisionmaking: Lessons from the Clean Air Act, 62 IowA L. REv. 713, 762-63 (1977). (reviewing courts, unencumbered with specialized institutional mission, play an indispensable corrective role); Sunstein, supra note 4 , at 463-78.

19. See supra note 12; see also Olson, The Quiet Shift of Power: Office of Management \& Budget Supervision of EPA Rulemaking Under Executive Order 12,291, 4 VA. J. NAT. RESOURCES L. 1, 40 (1984).

20. See supra text following note 12 .

21. See R. MELNICK, supra note 13, at 379 (notwithstanding Melnick's quite critical view of the role of the courts in environmental law); Pedersen, supra note 18, at 59-60. 
the regulatory programs of the United States demonstrates that judicial decrees are important in producing executive compliance with law. ${ }^{22}$

It is also possible to show that aggressive judicial review has often provided significant benefits both in bringing about desirable regulatory initiatives and in preventing unreasonable or unlawful regulation. Examples are numerous, and indeed on balance extraordinary. Judicial initiatives helped bring about regulation of $\mathrm{DDT}^{23}$ and airborne lead ${ }^{24}$; control of asbestos, beryllium, and mercury ${ }^{25}$; regulation of atmospheric loading, which produces acid deposition, ${ }^{26}$ disclosure requirements for hazardous chemicals ${ }^{27}$; and regulation in the workplace of ethylene oxide and formaldehyde. ${ }^{28}$ The federal courts also prevented the government from eliminating passive restraint rules. ${ }^{29}$ The Supreine Court's invalidation of an extremely hasty and ill-considered decision to scrap those rules will ultimately save inany lives. In the areas of communications and broadcasting, an aggressive judiciary has helped ensure high quality programming, diversity, local control, and sensitivity to the interests of minority groups. ${ }^{30}$ In addition, the Prevention of Significant Deterioration (PSD) program-calling for, among other things, protection of pristine areas from environmental degradation-is a product of an aggressive federal court. ${ }^{31}$

22. See, e.g., Office of Management and Budget, Executive Office of the PreslDeNT, Regulator Y Program of the United States Government 50, (Apr. 1, 1986-Mar. 31, 1987) [hereinafter Regulatory Program of the UNited States GovernmenT] (discussing Department of Commerce amendments to the Coastal Zone Management Act in order to conform to Secretary of the Interior v. California, 464 U.S. 312 (1984), which held federal sale of outer continental shelf oil and gas leases not activity directly affecting coastal zone within meaning of $\S 307(\mathrm{c})(2)$ ). See generally ReGUlatory PROGRAM OF THE UNITED STATES, 1985-90 (filled with illustrations of regulatory initiatives undertaken because of judicial compulsion).

23. Environmental Defense Fund v. Ruckelshaus, 439 F.2d 584 (D.C. Cir. 1971).

24. NRDC v. Train, 545 F.2d 320 (2d Cir. 1976).

25. Environmental Defense Fund v. Ruckelshaus, 3 Envtl. L. Rep. (Envtl. L. Inst.) $\Uparrow 20,173$ (D.C. Cir. 1973).

26. NRDC v. EPA, 489 F.2d 390 (5th Cir. 1974), rev'd, 421 U.S. 60 (1975).

27. United Steel Workers v. Pendergrass, 819 F.2d 1263 (3d Cir. 1987), cert. granted, 109 S. Ct. 2061 (1989).

28. Public Citizen Health Research Group v. Tyson, 796 F.2d 1479, 1507 (D.C. Cir. 1986); International Union, UAW v. Donovan, 590 F. Supp. 747, 753 (D.D.C. 1984).

29. Motor Vehicle Mfrs. Ass'n v. State Farm Mut. Auto. Ins. Co., 463 U.S. 29, 38, 57 (1983) ("[E]ach year an estimated 9,000 more lives will be saved, and tens of thousands of serious injuries will be prevented [because of the passive restraint requirement].").

30. See Stewart, supra note 10, at 1582.

31. See, e.g., Sierra Club v. Ruckelshaus, 344 F. Supp. 253, 256 (D.D.C. 1972) (granting preliminary injunction to prevent EPA approval of state plans that would allow air pollution to rise to secondary levels pursuant to the Clean Air Act of 1970). As we will see, the PSD program is far from perfect, see infra notes 46-52 and accompanying text; but the basic idea of protecting pristine areas is sound. 
In addition to bringing about regulatory initiatives that are desirable, courts have played an important role im ensuring against overzealous or irrational regulation. Here too, the aggregate picture is quite extraordinary and reveals judicial protections against many ill-considered intrusions. For example, courts have invalidated an indefensible secondary standard for sulfur dioxide; ${ }^{32}$ struck down draconian regulation of the automobile ${ }^{33}$ and cement industries; ${ }^{34}$ required a quite sensible slowing of a "significant risk" before OSHA may regulate the workplace;35 and invalidated extremely aggressive transportation control plans written by the EPA. ${ }^{36}$

Examples of this sort amount to little inore tlian anecdotes. This can hardly dispose of the issue. But they are highly suggestive. They indicate that a world without aggressive judicial review miglit well suffer from increases in lawlessness, carelessness, overzealous regulatory controls, and inadequate regulatory protection. Aggressive judicial review has produced important ex ante and ex post benefits in numerous settings; and although the evidence is largely anecdotal and far from systematic, it must suffice absent a more sustained investigation into the issue.

\section{Proposed Principles to Increase "Net Benefits"}

We have seen that it is difficult to say in the abstract whether aggressive judicial review of administrative action has produced, or will produce, sigrificant advantages. In tliese circumstances, a major task is to develop principles of interpretation that will improve the situation. Public law tlius far lacks a set of interpretive norms that are well-adapted to the purposes, operation, and occasional failures of regulatory legislation. For this reason, the area of statutory construction of adninistrative behavior remains undeveloped. In this section, I outline, in summary fashion, some principles that courts might bring to bear on regulatory

32. See Kennecott Copper Corp. v. EPA, 462 F.2d 846, $850-51$ (D.C. Cir. 1972) (remand to agency for further explanation of basis for secondary air quality standard for sulfur oxides).

33. International Harvester Co. v. Ruckelshaus, 478 F.2d 615 (D.C. Cir. 1973).

34. Portland Cement Ass'n v. Ruckelshaus, 486 F.2d 375 (D.C. Cir. 1973), cert. denied, 417 U.S. 921 (1974).

35. See Industrial Union Dep't, AFL-CIO v. American Petroleum Inst., 448 U.S. 607, 642-62 (1980) (remanding benzene regulation for determination whether benzene use poses siguificant risk under OSHA); see also Rose-Ackerman, Progressive Law and Economics-and the New Administrative Law, 98 YAle L.J. 341, 364-66 (1988) (supporting part of analysis in Industrial Union Dep't).

36. See South Terminal Corp. v. EPA, 504 F.2d 646, 665-67, 670, 681-82 (1st Cir. 1974) (approval of EPA emissions standards denied pending further hearings on the technical basis for the standards); Texas v. EPA, 499 F.2d 289, 308, 315-16, 318, 320-22 (5th Cir. 1974) (finding arbitrary and capricious some aspects of EPA response to Texas' air quality implementation plan), cert. denied, 427 U.S. 905 (1976). 
problems. ${ }^{37}$ Most of these principles, which might be embodied in clear statements principles or interpretive "canons," already have some support in existing law.

\section{A. Proportionality.}

Statutes should be construed so that the aggregate social benefits are proportionate to the aggregate social costs. This principle, implicit in some of the recent cases, ${ }^{38}$ recognizes that a proportionality principle will likely produce sensible regulation and therefore is the appropriate understandimg to attribute to Congress under normal circumstances. The principle also recognizes that well-organized groups are sometimes able to obtain legislation that would not be the outcome of a well-functioning deliberative process; that bureaucratic incentives can press agencies in the direction of overzealous enforcement; that the statutory text is sometimes an impulsive reaction to short-term problems; that temporary pubhic concern can result in hasty drafting; and that Congress is not able to focus on all applications of statutory standards. The purpose of the proportionality principle is to ensure that in the absence of a clear legislative statement, statutes are understood to impose costs commensurate with their benefits. Under this view, of course, costs and benefits need not be measured technically, in accordance witl the willingness-to-pay criterion, but instead would be assessed in accordance witl looser understandings about proportionality.

The proportionality principle has played a role in two important recent decisions. In Industrial Union Department v. American Petroleum Institute, the Supreme Court interpreted the toxic substances provision of the Occupational Safety and Healtil Act to require a sliowing of a "significant risk" before the Secretary of Labor can regulate toxic substances. ${ }^{39}$ The plurality referred explicitly to the problem of de minimis health benefits imposed for huge expense. 40 In $N R D C$ v. EPA, the Umited States Court of Appeals for the D.C. Circuit concluded that the EPA could take account of economic and teclinological feasibility in setting the "margin of safety" for hazardous pollutants. ${ }^{41}$ Here too the court expressed concern that an alternative interpretation miglit require

37. A much more detailed treatment of this problem can be found in a forthcoming article, Sunstein, Interpreting Statutes in the Regulatory State, 103 HARV. L. REv. (forthcoming 1989) and a forthcoming book, C. SUNSTEIN, The RegulatoRY STATE (1989 draft). Both deal with numerous interpretive principles with which to approach regulatory statutes.

38. See, e.g., Industrial Union Dep't, 448 U.S. at 639-59; NRDC v. EPA, 824 F.2d 1146 (D.C. Cir. 1987).

39. 448 U.S. at $639-40$.

40. Id. at 645 .

41. 824 F.2d 1146, 1163 (D.C. Cir. 1987). 
regulation that was irrational because it imposed enormous costs for minimal gains. ${ }^{42}$

Both of these decisions can be understood as responsive to the fact that stringent statutory requirements tend to bring about a paradoxical regime of simultaneous over-regulation and under-regulation. When the statute does not contain a proportionality principle, agencies tend to over-regulate those substances that get on the agenda; but they are simultaneously reluctant to regulate many substances at all, which therefore go entirely uncontrolled. One consequence of draconian standards is thus to leave the marketplace unregulated in many settings. ${ }^{43}$ A proportionality principle is a useful corrective.

B. De Minimis Exceptions.

It follows from the proportionality principle that administrators should generally be authorized to refuse to impose costly regulations for highly speculative or minimal gains. ${ }^{44}$ Many courts have reached precisely this conclusion, holding that in the absence of a clear congressional statement, admimistrators may make de minimis exceptions to regulatory controls. ${ }^{45}$ Indeed, courts probably should require such exceptions in the absence of explicit statutory text or plausible substantive justifications to the contrary.

42. Id. at $1163-66$.

43. See J. Mendeloff, The Dilemma of Toxic Substance Regulation: How OverREGULATION CAUSES UNDERREGULATION AT OSHA 90-99 (1988); Rose-Ackerman, supra note 35, at 361-64.

44. Courts have reached somewhat conflicting conclusions on this point, although the general background rule seems to be in favor of de minimis exceptions. See Public Citizen v. Young, 831 F.2d 1108, 1122 (D.C. Cir. 1987) (Delaney Clause does not contain implicit de minimis exception for carcinogenic dyes), cert. denied, 108 S.Ct. 1470 (1988); Alabama Power Co. v. Costle, 636 F.2d 323, 360-61 (D.C. Cir. 1979) (courts should be reluctant to apply literal terms of statute to mandate pointless expenditures of effort); Monsanto Co. v. Kentucky, 613 F.2d 947, 954 (D.C. Cir. 1979) (statutory scheme permits de minimis exceptions in situations that clearly present no public health or safety concerns). See generally Gilhooley, Plain Meaning, Absurd Results and the Legislative Purpose: The Interpretation of the Delaney Clause, 40 ADMIN. L. REV. 267 (1988) (examining rejection of de minimis exception to the Delaney Clause).

45. See Bowen v. Yuckert, 482 U.S. 137 (1987) (severity regulation); Coalition on Sensible Transp., Inc. v. Dole, 826 F.2d 60, 63 (D.C. Cir. 1987) (end use statute broad enough to include minimal "uses" of parkland); Sierra Club v. United States Dep't of Transp., 753 F.2d 120, 126 (D.C. Cir. 1985) (agency has broad discretion to waive the statutory requirement of producing an Environment Impact Statement); Alabama Power Co. v. Costle, 636 F.2d at 360 (EPA may exempt de minimis situations). See generally Fiksel, Toward a De Minimis Policy in Risk Regulation, 5 RIsK ANALYSIS 257 (1985) (discussing the use of de minimis risk threshold in the OSHA Regulation of benzene and proposing a series of fundamental principles and societal objectives to be considered in setting similar thresholds); Mumpower, An Analysis of the De Minimis Strategy for Risk Management, 6 RISK ANALYSIS 437 (1986) (analysis of risks and risk management decisions should include both old and new risks, as well as organizational, institutional, political, and societal factors). 


\section{Understanding Systemic Effects.}

Regulation is frequently unsuccessful, or less successful than it should be, because of a legislative or administrative failure to understand the complex systemic effects of governmental controls. The problem of perverse unintended consequences is a pervasive one. ${ }^{46} \mathrm{~A}$ similar failure has undermined interpretive efforts by the federal courts. Consider, for example, the court's creation-in the face of an ambiguous text-of the "prevention of significant deterioration" (PSD) program in Sierra Club v. Ruckleshaus. ${ }^{47}$ In that case, the court ruled that state implementation plans under the Clean Air Act ${ }^{48}$ must include provisions not merely complying with national air quality standards, but also designed to prevent the degradation of air currently cleaner than required by those standards. ${ }^{49}$ One of the court's apparent goals was to ensure that federal environmental policy would protect visibility in currently pristine areas. ${ }^{50}$ While its decision has promoted that goal to some degree, it also has been immensely expensive, has delayed the substitution of lowsulphur western coal for high-sulfur eastern coal, and has perversely protected dirty existing plants against replacement with cleaner new ones. ${ }^{51}$ It is far from clear that the environment is better off as a result. The Sierra Club court was unaware of these effects. Because the statutory basis for the decision was quite thin, an understanding of the environmental and nonenvironmental costs associated with the PSD program might well have led to a narrower or even contrary result.

Similar examples are provided by the Supreme Court's OSHA decisions, in which the Court, or several of its members, appeared to assume that greater protection for workers would follow automatically from more stringent statutory requirements. ${ }^{52}$ As we have seen, this assumption disregards the fact that stringent requirements tend to lead an agency not to regulate at all, thus producing under-regulation. It also

46. See, e.g., J. MENDELOFF, supra note 43, at 4-8 (describing how over-regulation causes under-regulation); R. CRANdall, Regulating the Automobile 5 (1986) (discussing how regulation of new cars keeps old dirty cars on road longer); R. CRANDALL, CONTROLI.ING INDUSTRIaL Pollution: The Economics and Politics of CleAN AlR 41 (1984) (discussing ways in which regulation of new sources perpetuates dirty sources).

47. 344 F. Supp. 253 (D.D.C. 1972).

48. 42 U.S.C. $\$ \S 7401(b)(1), 7410$ (1982).

49. 344 F. Supp. at 256.

50. See R. MELNICK, supra note 13, at 81 (most frequently mentioned goal is to protect visibility in pristine areas).

51. See id. at 76.

52. See supra note 35; see also American Textile Mfrs. Inst., Inc. v. Donovan, 452 U.S. 490 , 540-41 (1982) (OSHA places pre-eminent value on safe and healthful workplace, limited only by feasibilty). 
ignores the risk that such requirements might impose costs that ultimately will be borne by workers themselves.

In short, courts dealing with regulatory issues commonly misunderstand the systemic effects of administrative controls, and act as if the decision will create only ex post winners and losers in the particular case. This misunderstanding leads to statutory construction that is uninformed by the real-world impact of regulation - and the real-world impact, while not by itself decisive, is frequently relevant to the question of statutory meaning.

\section{Cautious Approach to Legislative History.}

Legislative history is sometimes written by one or another side in a dispute over the content of the law, and the history will sometimes reflect a view whose advocates were unable to prevail during congressional deliberations. ${ }^{53}$ Moreover, Congress enacts laws, not the comments of some of its meinbers about what those laws mean. All this supports a firm principle in favor of the priority of statutory text to statutory history.

Properly understood, this principle does not call on courts to disregard the history, but counsels them to give the history limited weight in cases of arguable conflict. Consider, for example, section 111 of the Clean Air Act, ${ }^{54}$ an ambiguous provision that could be interpreted to call for administrative concentration on environmental benefits, but whose conference report language suggests an effort-unsuccessful in Congress as a whole-to convert the environmental laws into protectionism for eastern coal producers. ${ }^{55}$ A court that accorded great weight to the history to clarify ambiguous text might well have permitted the conference report to bring about that conversion. But a court that accepted the priority of the text would interpret it to ensure against a statutory "deal" destructive of both the environment and the economy.

\section{E. Coordination.}

It should come as no surprise that the post-New Deal proliferation of regulatory programs has led to inconsistency and sometimes incoherence in the law. For example, the standards for regulating carcinogens

53. For a vivid example, see B. ACKerman \& W. Hassler, Clean CoAl/Dirty Air 52 (1981); see also the discussion by Justice Scalia in Scalia, Judicial Deference to Administrative Interpretations of Law, 1989 DUKE L.J. 510-12; see generally INS v. Cardoza-Fonseca, 480 U.S. 421, 45254 (1987) (concurrence by Scalia on congressional intent and agency interpretation of statutory language).

54. 42 U.S.C. $\$ 7401$ (1982).

55. See B. ACKerman, \& W. HAssler, supra note 53, at 30-33. 
are notoriously variable, calling for excessive controls in some areas and unduly weak regulation in others. ${ }^{56}$ The absence of centralization has led to regulatory failures in numerous areas. ${ }^{57}$

A partial solution would call on courts to employ clear statement principles of statutory construction so as to help bring about consistency and coordmation in the law. A judicial role of this sort has clear precedent both in the old idea that statutes governing the same subject matter should be construed together ${ }^{58}$ and in contemporary administrative law. In Bob Jones University v. United States, for example, the Supreme Court held that the Internal Revenue Service could not grant tax deductions to private schools that discriminate on the basis of race..$^{59}$ The source of the prohibition was a statute giving deductions to institutions serving charitable purposes, but with an implicit exception when "public policy" requires denial of the deduction. There is no doubt that, when the statute was initially enacted, "public policy" did not prohibit deductions to institutions that discriminated on the basis of race. Racial discrimination in education was common at the time, and it could not plausibly be suggested that the enacting Congress thought that discriminatory scliools violated public policy. The Bob Jones decision is best understood as an effort to ensure that the IRS takes account of the widespread social antagonism toward racial discrimination, since that antagonism now forms a part of the general thrust of conteniporary "public policy." The underlying idea was that the statute should be construed in a way that conforins to current views about racial discrimination in education. Some cases liniting agency authority to inipose significant costs for uncertain or speculative benefits can be understood in similar terms, as an effort to bring about coherence in the law and conformity with current norms and practices. ${ }^{60}$

56. See Regulatory Program of the United States, supra note 22, at 259-60 (OSHA changes to Carcinogen Policy (29 C.F.R. 1990) in light of the "different approaches" to "regulatory requirements for research laboratories and the construction, agriculture, and maritime industries").

57. See, e.g., Huber, Electricity and the Environment: In Search of Regulatory Authority, 100 HARV. L. REV. 1002, 1003 (1987); R. KATZMAN, INSTITUTIONAL DISABILITY 1 (1985).

58. See Flint Ridge Dev. Co. v. Scenic Rivers Ass'n, 426 U.S. 776, 789-93 (1976) (reconciling the National Environmental Policy Act with the Disclosure Act); Sanford v. Commissioner, 308 U.S. 39, 42 (1939) (finding the federal gift tax supplementary to the estate tax); Preston State Bank v. Ainsworth, 552 F. Supp. 578, 580 (N.D. Tex. 1982) (ruling that the bank names provision of the National Banking Act complements but does not preempt a Texas unfair compensation statute); Daigneault v. Public Fin. Corp. 562 F. Supp. 194, 196 (D.R.I. 1983) (aligning allegedly conflicting provisions of the Truth in Lending Act); Jones v. Ilinois Dep't of Rehabilitation Servs., 504 F. Supp. $1244,1255-58$ (N.D. Ill. 1981) (construing various amendments of handicapped discrimination statute to assess responsibility for student aides), aff'd, 689 F.2d 724 (1982).

59. Bob Jones Univ. v. United States, 461 U.S. 574 (1983).

60. See, e.g., Industrial Union Dep't, AFL-CIO v. American Petroleum Inst., 448 U.S. 607, 608 (1980) (restricting the authority of the Secretary of Labor to impose elevated standards for a 


\section{F. Obsolescence.}

A large problem for modern regulation is that of obsolescence-statutory requirements that are inconsistent with new developments of fact, policy, and law. Statutes may no longer be consistent with widely held social norms. The legal background may have changed dramatically as a result of judicial and legislative innovations; the factual assumptions underlying an old statute may no longer hold. In all of these cases, the question is whether changing circumstances justify a change in interpretation.

In the areas of banking, broadcasting, and carcinogen regulation, judicial interpretation has sometimes been a straightforward response to changed circuinstances. ${ }^{61}$ Here it is implausible to resolve statutory ambiguities by asking how Congress would have answered the question at the time of enactment. In hight of the changed nature of the relevant markets, such an approach would be a recipe for absurdity. At least if the language so permits, there is no alternative but to extrapolate purposes at a certain level of generality and to assess the changed circuinstances in light of those purposes.

Consider, as a particular example, the problein of interpreting the Delaney Clause. ${ }^{62}$ As was seen, the Clause contains a general prohibition on the use of substances that "induce" cancer as food additives, and was enacted in a period when carcinogens could be detected only at high-risk levels. The enacting Congress assumed that carcinogenic substances were both rare and extremely dangerous. Now, however, carcinogenic substances appear omnipresent, and often pose little danger. Should tlie statute be interpreted to permit de minimis exceptions in a time in which carcinogens can be detected at exceptionally low levels posing trivial risks to health?

The Food and Drug Administration (FDA), invoking the changed character of scientific knowledge, says yes; a federal court has said no. ${ }^{63}$ In the court's view, the provision said what it meant and meant what it said, and that was that. But read in its context, there was no such clarity in the Delaney Clause. Congress simply did not focus on the question of de minimis risks. Indeed, it could not have done so in liglit of the state of scientific knowledge with respect to carcinogenic substances. It was therefore a mytli to say that the congressional enactment resolved the

\footnotetext{
"risk free workplace"); NRDC v. EPA, 824 F.2d 1146, 1164 (D.C. Cir. 1986) (restricting EPA from considering cost and technical feasibility in determining what is "safe").

61. See Langevoort, Statutory Obsolescence and the Judicial Process: The Revisionist Role of the Courts in Federal Banking Regulation, 85 MICH. L. REV. 672 (1987).

62. See supra note 5.

63. See supra note 16.
} 
question in the face of unanticipated scientific developments. Nor can it be said that the FDA's de minimis exception "amended" the Clause. The question is the ineaning of the clause in light of the new circumstances. Might the word "induce" contain a de minimis exception? The answer to that question will inevitably depend on interpretation.

A inore nuanced approach to the problein of obsolescence can be found in judicial constructions of statutes of the 1920s and 1930s requiring old-line agencies to take account of environmental concerns. ${ }^{64}$ Here the legal background has changed so dramatically that what might seem to be a straightforward interpretation of the old statutes would produce incoherence. The problem of obsolescence also helps explain the courts' narrow construction of provisions of the Uniform Commercial Code (UCC) that had not anticipated the consumer revolution in the law of products liability. 65

Dean Calabresi has argued that courts should have the power to invahdate obsolete statutes, returning them to the legislature for reconsideration. ${ }^{66}$ A judicial role of this sort would be extremely controversial, and properly so. The principal problem posed by obsolescence or changed circumstances is that it makes interpretation in the ordinary sense far more difficult. Efforts to translate statutes into new settings cannot be made simply by asking what the statute meant when it was enacted. A principle that calls for courts to exercise some creativity here provides a far less intrusive function for the courts, and it has unmistakable foundations in current law.

\section{CONCLUSION}

The question whether aggressive judicial review of administrative action has produced "net benefits" poses difficulty nost notably because of the absence of clear criteria by which to make the assessment. Courts have the responsibility both to ensure legality and to prevent arbitrariness, and a decision to bring about compliance with the governing statute may or may not produce more sensible regulation. The absence of clear criteria and the lack of good empirical data make it exceptionally difficult to evaluate the strengths and weaknesses of aggressive judicial review. In the abstract, one could imagine scenarios in which such review would be

64. See, e.g., Scenic Hudson Preservation Conference v. Federal Power Comm'n, 354 F.2d 608 (2d Cir. 1965), cert. denied, 384 U.S. 941 (1966) (FPC licensing and related orders set aside for failure to support decision with sufficient evidence in the record and for ignoring relevant factors and failing to analyze possible alternatives to a hydroelectric power plant project).

65. See Peters, Common Law Judging in a Statutory World: An Address, 43 U. PITT. L. REv. 995, 1003 (1982).

66. See G. Calabresi, A Common law for the Age of Statutes 146-62 (1985). 
alternatively indispensable and disastrous. Nonetheless, there is some basis for believing that aggressive judicial review has, in many settings, mcreased the incidence of legality, prevented arbitrariness, ensured against undesirable regulation, and brought about regulatory controls that have saved hives or otherwise accomplished considerable good.

A major gap in current administrative law is the lack of an understanding of the characteristic functions and failures of the regulatory process, and a derivative understanding of the judicial role. Sympathetic engageinent with regulatory purposes, together with a solid understanding of regulatory pathologies, ultimately might lead to a set of principles by which courts could indeed bring about "net benefits" through judicial review. No one should argue that the judiciary should play the central role in ensuring legality, rationality, or justice in the admimistrative process. But it would be difficult to deny that a judiciary suitably sensitive to the functions and failures of the regulatory state imight well make things better rather than worse. 